\author{
N. Özhatay, R. Wallis, R. B. Wallis \& M. Koçyiğit
}

\title{
A new Fritillaria species from Mediterranean region of Turkey; Fritillaria asumaniae
}

\begin{abstract}
Özhatay, N. Wallis, R., Wallis, R. B. \& Koçyiğit, M.: A new Fritillaria species from Mediterranean region of Turkey; Fritillaria asumaniae. — Fl. Medit. 25 (Special Issue): 199208. 2015. - ISSN: 1120-4052 printed, 2240-4538 online.

Fritillaria asumaniae R. Wallis, R. B. Wallis \& N. Özhatay from Antalya province, situated in the Mediterranean region of Turkey is described as a new species. Approximately 20 species of the genus Fritillaria occur in Mediterranean region of Turkey, nearly 50\% of which are endemic. In habit and shape of the perigone, the new species is reminiscent of $F$. forbesii Baker, a Turkish endemic species distributed around Muğla province and $F$. elwesii Boiss. scattered throughout SW Turkey and Aegean Islands. It differs from F. forbesii in its very dark brownish or blackish flowers, anthers and pollen grains. It also differs from $F$. elwesii in its undivided style, lack of green fascia on the perigone segments, the dark colored pollen grains and absence of bulbils. Description of the new species, taxonomic relationships, anther and pollen grain characteristics with color photographs are given.
\end{abstract}

Key words: Fritillaria, SEM, Mediterranean, Turkey.

\section{Introduction}

Approximately 156 taxa of the genus Fritillaria are accepted worldwide (Rix 2001). In Turkey the genus is represented by 35 species and 6 subspecies totaling 41 taxa, of which 16 are endemic. 15 new species have been collected for the first time in Turkey and their type specimens preserved therein (Rix 1984; Özhatay 2000; Tekşen 2012). The Mediterranean region is a particularly important area for the genus in Turkey (Fig. 1). Herein we describe a further new taxon from the region: Fritillaria asumaniae.

Whilst walking in the forest in the foothills of Tahtalı Dağ, near Antalya, on November 8th 2008, R. \& R. B. Wallis noticed a large number of Fritillaria capsules in the dense undergrowth. Enquiries made of others who had been there before, informed us that the flowers were predominantly black and that, in spite of the colour, this could be a disjunct site for F. forbesii. Further investigation on April 7th 2011, whilst the plants were in flower, made us realise that there were significant differences from the latter and that we had found an undescribed species growing 


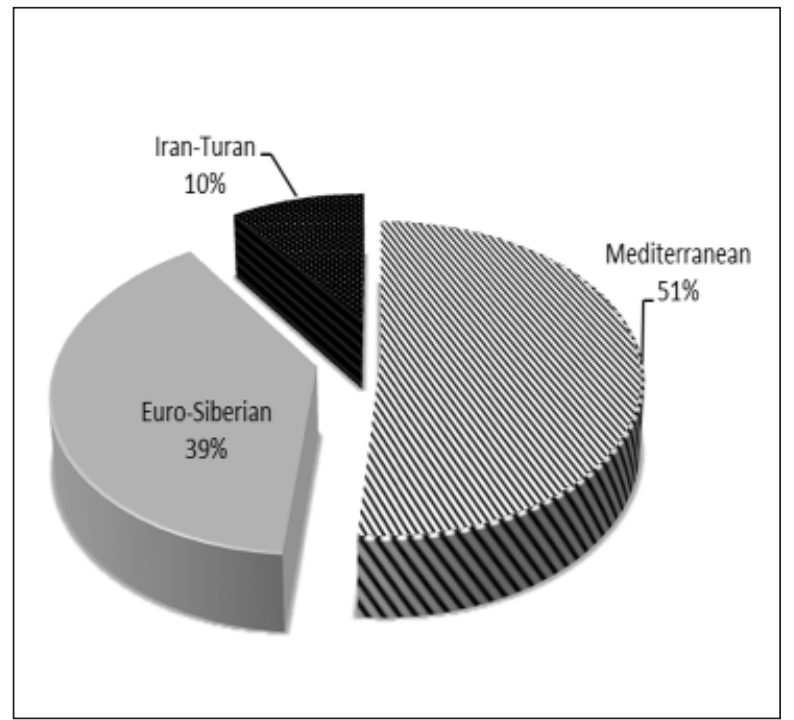

Fig. 1. The distribution of Fritillaria species within the three floristic region of Turkey (Tekşen 2012).

within a $\mathrm{km}$ of a popular tourist resort. It is widespread in and around the Olimpos Beydağları National Park and along the Lycian Way and it is a surprise that it has not been reported before.

\section{Materials and methods}

The specimens were collected during flowering time and were checked with the relevant literature (Tutin 1980; Rix 1984, 2001; Townsend 1985; Rechinger 1990; Özhatay 2000; Wallis \& Wallis 2003; Tekşen \& Aytaç 2008; 2011; Tekşen 2012) and compared with the herbarium specimens in ISTE (Istanbul University, Faculty of Pharmacy Herbarium).

Other examined species kept in ISTE:

F. forbesii; C2 Muğla, Babadağ,Fethiye-Ölüdeniz, Ocakköy,Pinus brutia forest, limestone rocks,500 m, 19.03. 1992, N.Özhatay, A.Byfield, S.Atay (ISTE 64040)!

F. elwesii; C3Antalya:Manavgat-Topraktepe, near Taşkesiği, 100 m, 30.03.1975, T. Baytop (ISTE 31386)!, around Akseki, 04.1987, A. Attila. (ISTE 57760)!

Pollen samples were taken from herbarium materials for palynological studies. Pollen grains of specimens for LM investigations were prepared according to the method proposed by Wodehouse (1935) in Istanbul University, Faculty of Pharmacy, and Department of Pharmaceutical Botany and coated with gold for scanning electron microscope (SEM) studies. The SEM micrographs were taken with a JEOL 6510-LV JSM microscope. The descriptive terminology of Faegri and Iversen (1992) was used. The general pollen description was based on the SEM investigation. 
Fritillaria asumaniae R. Wallis, R. B.Wallis \& N. Özhatay, sp. nov. - Fig. 2, 3.

Type: C3 Antalya. Kemer, west of Göynűk, forest in deep leaf soil amongst limestone rocks under tall pine woodland, 250 m. 29.111.2012, N. Özhatay and A. Kavgacl (Holotype: ISTE 106610!).

Other examined specimen C3 Antalya, Kemer, Tahtalıdağ, Peynirlik-Kızılalan 8001600 m, 04.05.1979, H.Peşmen 4628, A. Güner (ISTE 52595)!

Etymology: The species is named after Asuman Baytop (1920 - 2015) who was a well known Türkish botanist and sadly passed away this year.

Bulb spherical without bulbils. Stem 25-60 cm smooth. Leaves glaucous, 4-5 (7), alternate, linear-lanceolate, lowest $9.5 \times 1.2 \mathrm{~cm}$, with a single bract leaf, $4.5 \times 0.3 \mathrm{~cm}$. Leaves on unflowered bulbs ovate-lanceolate up to $6.5 \times 3.5 \mathrm{~cm}$. Flowers single, narrowly conical, segments dark brown-black with occasional small light spots, sometimes with a yellowish distal margin, untessellated, $20 \times 8 \mathrm{~mm}$. Nectary indistinct, greenish, at the base of the perigone, $3-4 \times 2 \mathrm{~mm}$. Filaments greenish white, $10 \mathrm{~mm}$. Anthers dark brown. Style clavate, trifurcate, undivided, $8 \times 1.5 \mathrm{~mm}$ papillose. Capsule unwinged.

Growing in partial to deep shade of large Pinus brutia Ten. trees, in deep leaf mould soil amongst limestone rocks. 225-500 m.

Ecology and distribution: Fritillaria asumaniae is quite a tall (up to $60 \mathrm{~cm}$ ) compared to other species probably because of its environment of tall undergrowth under the shade of pine trees in Antalya Province (Fig. 4). It shares this environment with beautiful mature trees of Arbutus andrachne L. and several species of deciduous shrubs which are only just coming into leaf when the new species is flowering. The area has a number of orchids of which we only noted Orchis anatolica Boiss. in flower at the same time. There are also a large number of Cyclamen graecum subsp anatolicum Ietsw. and Galanthus peshmenii A.P.Davis \& C.D.Brickell which occupy the lower and the upper forest respectively and both of which overlap the altitude range of F. asumaniae.

Fritillaria asumaniae shows little variation and about half of the flowers observed are entirely dark brown with small white dots and the other half have a small yellow mark in the centre of the tip of both inner and outer tepals. After considerable searching we found just one specimen, amongst approximately 100 others, with dingy yellow flowers.

Anther and pollen morphology of the new species was compared with $F$. forbesii and $F$. elwesii (Fig. 3). The general description can be given as follows:

The anthers of $F$. elwesii are 5-8 $\times 0.9-1 \mathrm{~mm}$ and those of $F$. forbesii are 4-8 $\times 0.8-0.9$ $\mathrm{mm}$, whereas $F$. asumaniae has the smallest anthers among the three species (4-6 $\times 0.9-1$ $\mathrm{mm})$. Those of all the investigated species are apiculate at apex. The inner and outer surfaces are fossulate, with irregular grooves.

The main features of the investigated pollen are summarised in Table 1. Size and shape; The shape of pollen grains in the investigated Fritillaria is radially symmetrical, heteropolar, prolate according to the LA/SA ratio. The long axis (LA) 42.46-56.31 $\mu \mathrm{m}$ and short axis (SA) 30.46-41.85 $\mu \mathrm{m}$ based on LM. F. asumaniae has the largest pollen grain. Aperture; All the investigated pollen grains are operculate, monosulcate. Fritillari forbe- 


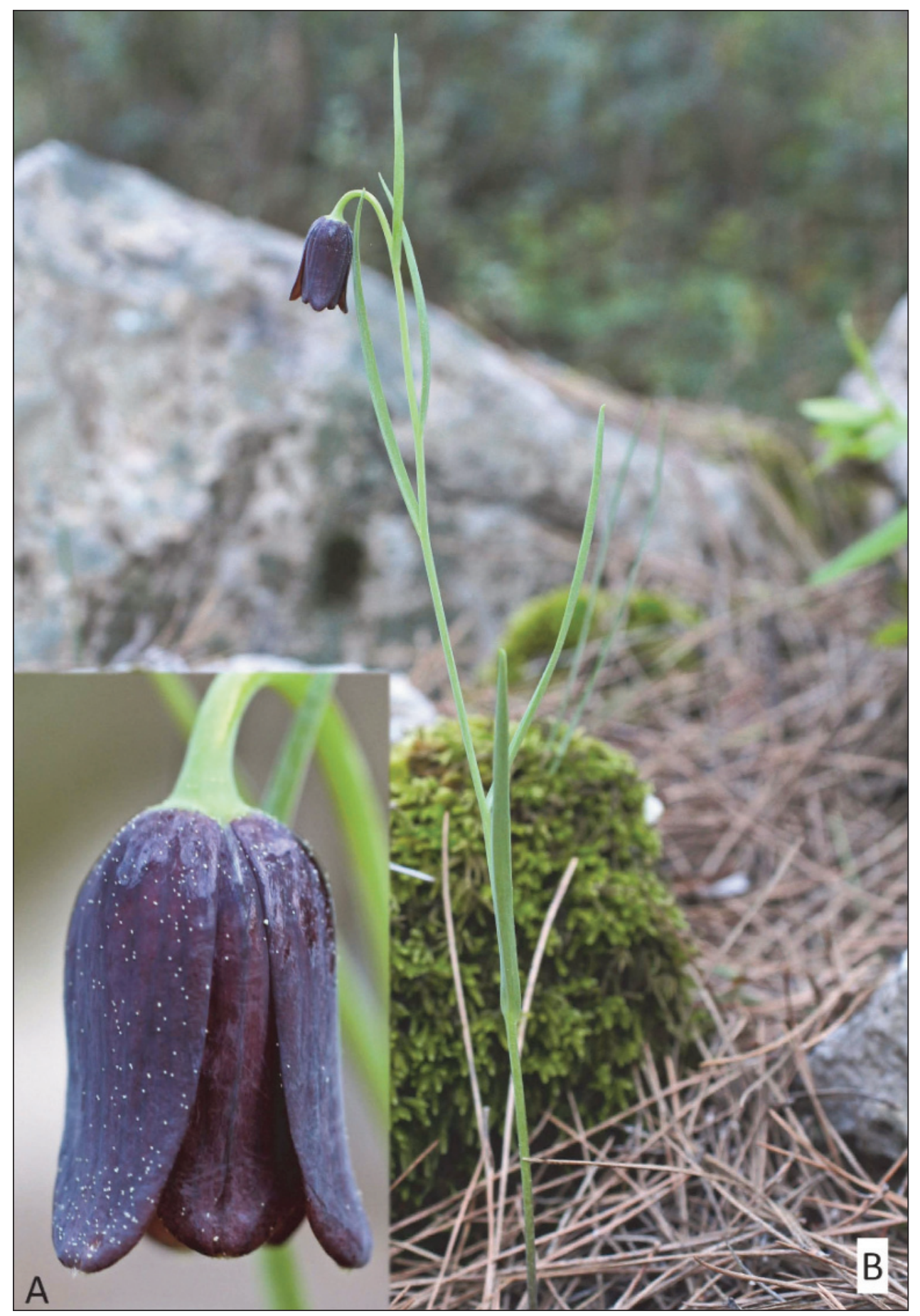

Fig. 2. Fritillaria asumaniae: A) Perigone, B) In the field. 



3

Fig. 3. The main morphological features of Fritillaria forbesii (1), F. elwesii (2), F. asumaniae (3): a. Outer tepals; b. Inner tepals; c. Stamen; d. Pistil.

sii has the longest and the widest sulcus, its length is $41.54 \mu \mathrm{m}$ and its width is $10.77 \mu \mathrm{m}$ based on LM. The sulcus membrane is verrucate in all three Fritillaria species investigated. Exine, intine; The exine is tectate and 1.08-1.69 $\mu \mathrm{m}$ thick. Intine thickness ranges from 0.91 to $1.24 \mu \mathrm{m}$. The thickest exine and intine are observed on the new species, F. asumaniae. The ornamentation is reticulate, rugulate-reticulate, reticulate-perforate. Reticulateperforate sculpturing is observed in F. forbesii, rugulate-reticulate sculpturing is observed in $F$. elwesii and reticulate sculpturing is observed in the new species.



Fig. 4. Distribution of F. forbesii $\mathbf{\Lambda}$, F. elwesii $\bullet, F$ asumaniae 
204 Özhatay \& al.: A new Fritillaria species from Mediterranean region of Turkey;...

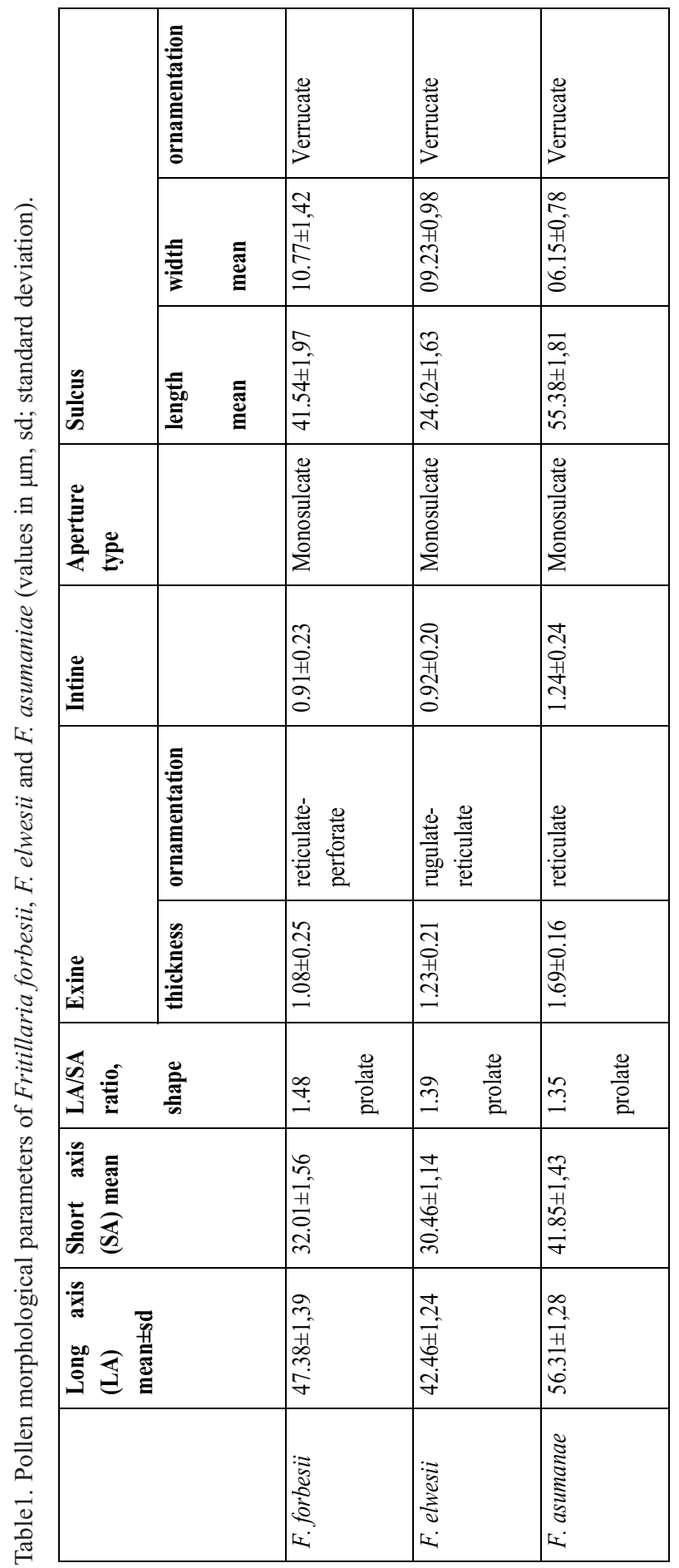




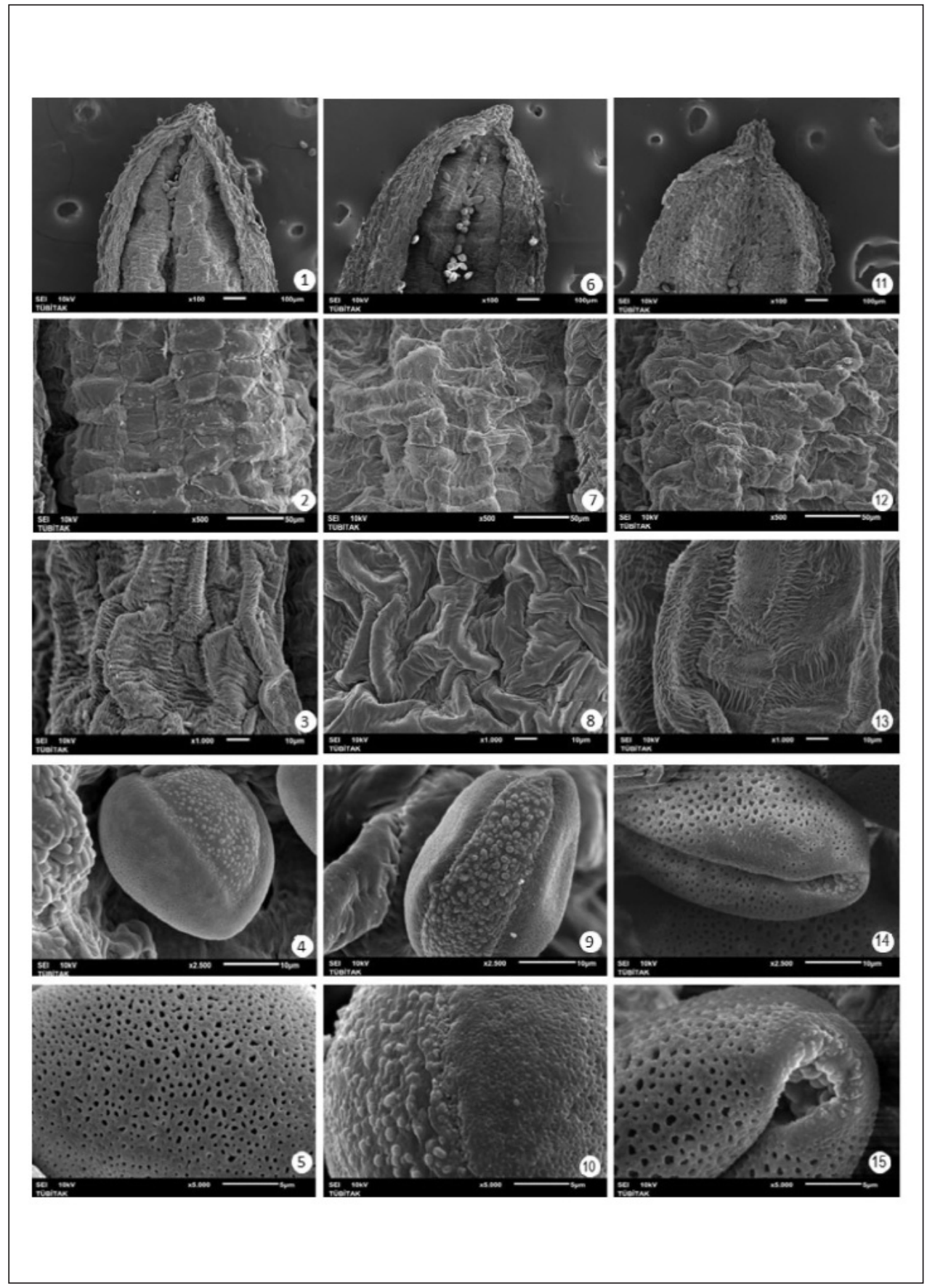

Fig. 5. Scanning electron micrographs of anthers (SEM $\times 100,500,1000)$ and pollen grains $(\mathrm{SEM} \times$ 2500, 5000): 1-5. F. elwesii, 6-10. F. forbesii, 11-15. F. asumaniae. Anther apex (1, 6, 11), inner surface of anther $(2,7,12)$, outer surface of anther $(3,8,13)$, pollen grains $(4,9,14)$, exine surfaces $(5,10,15)$. 


\section{Discussion and Conclusions}

Fritillaria asumaniae differs from $F$. forbesii Baker in several respects. With just the single exception described above, the flowers are very dark brown (greenish yellow in $F$. forbesii). The anthers and pollen are dark brown (yellow in F. forbesii). The stigma is markedly clavate and becomes very thick $(1.5 \mathrm{~mm})$ (linear and less than 1 $\mathrm{mm}$ in $F$. forbesii). The stem leaves are more than $10 \mathrm{~mm}$ wide (less than $5 \mathrm{~mm}$ wide in $F$. forbesii), a feature which is even more marked in the single leaves of unflowering seedlings $(F$. asumaniae $=35 \mathrm{~mm}, F$. forbesii $=4 \mathrm{~mm})$. Fritillaria forbesii is found on Baba Dağ and adjacent mountains, some $120 \mathrm{~km}$ to the west and has not been found in the intervening area.

According to Tekşen \& al. (2010), Fritillaria species were divided into 7 pollen types according to sulcus membrane (psilate, verrucate, verrucate-granulate, granulate, granulate-striate, rugulate, gemmate). Pollen grains of F.asumaniae and F. forbesii are type II, but the pollen of F.elwesii's is of type I.

Several other species of Fritillaria are known in the general area of Olimpos Beydağları National Park. Fritillaria acmopetala Boiss. is common especially on the south and east sides of the Tahtali Dağ ridge but differs in that it has narrower leaves and broader flowers. Plants named F. lycica were collected and described by Boissier nearby but it is clear that this is just a small form of $F$. acmopetala and is not the same as F. asumaniae (Baker 1874; Stapf 1928), F. asumaniae is easily separated from $F$. acmopetala by the shape of the flowers which is narrowly conical (campanulate with rounded shoulders in F. acmopetala) and particularly, by the stigma which is narrow and divided into three clear branches of at least $3 \mathrm{~mm}$ long in F. acmopetala and thickly clavate and undivided in $F$. asumaniae.

The difference between $F$. asumaniae and $F$. elwesii Boiss. is less straightforward and requires a combination of characters to be determined in order to distinguish the two species. The type locality of $F$. elwesii in the Dalaman River basin is $160 \mathrm{~km}$ to the south west and since it occurs near Kaş and throughout the southern Taurus mountains, one might expect it also to occur in Tahtali Dağ region, although it has never been reported there. Like F. acmopetala, F. elwesii usually has a divided stigma, lacking in $F$. asumaniae. However, in some specimens found near near Kaş, the stigma is undivided (E.M. Rix personal communication). It is however narrower than that of $F$. asumaniae. Fritillaria elwesii generally has flowers with marked green fascia (absent in F. asumaniae). Both species have brown anthers but the pollen is yellow in $F$ elwesii and brown in F. asumaniae. Moreover the inner segments are markedly broader than the outer segments in F. elwesii, yet similar or only slightly broader in F. asumaniae. Fritillaria elwesii is often a prolific producer of bulbils which result in quite large colonies of leaves whereas we have not observed bulbils on plants of $F$. asumaniae.

There is also one report of F. latakiensis Rix (Rix 1984) from near Kaş but again, although superficially similar to $F$. asumaniae it has a narrow, divided style.

For these reasons we consider $F$. asumaniae to be a new species and a surprising new addition to the flora of Turkey. F. asumaniae has been seen in several places in the forests of Tahtalı Dağ where it flowers in March and early April. 


\section{Acknowledgements}

We thank Dr. E. Martyn Rix for his advice and help in determination of the new species. Also thanks to the Turkish botanist Ali Kavgacı (Antalya) who accompanied Neriman Özhatay when collecting the type specimen.

\section{References}

Baker, J. G. 1874: Revision of the Genera and Species Tulipeae. - J. Linn. Soc. Bot. 14(76): 211-310. Özhatay, N. 2000: Fritillaria L. - Pp. 243-246 in: Güner, A., Özhatay, N., Ekim, T. \& Başer, K. H. C. (eds.). Flora of Turkey and the East Aegean Islands (suppl. 2), 11. - Edinburgh.

Rechinger, K. H. 1990: Fritillaria L. - Pp. 61-76 in Rechinger, K. H. (ed.), Flora Iranica, 165. - Graz.

Rix, E. M. 1984: Fritillaria. - Pp.284-302 in: Davis P. H., Mill, R. R., Tan, K. (eds). Flora of Turkey and the East Aegean Islands, 8. - Edinburgh.

- 2001: Fritillaria: A Revised Classification. - Edinburgh.

Stapf, O. 1928: Fritillaria acmopetale. - Curtis's Bot. Mag. t. 9148.

Tekşen, M. \& Aytaç Z. 2011: The revision of the genus Fritillaria L. (Liliaceae) in The Mediterranean region (Turkey). - Turk. J. Bot. 35: 447-478.

— \& - 2004: New Fritillaria L. taxa from Turkey. - Isr. J. Plant Sci. 52: 347-355.

— \& - 2008: Fritillaria mughlae (Liliaceae), a new species from Turkey. - Ann. Bot. Fenn. 45: 141-147.

— 2012: Fritillaria. - Pp.604-607 in: Güner, A., Aslan, S., Ekim, T., Vural, M. \& Babaç, M. T. (eds.). Türkiye Bitkileri Listesi (Damarlı Bitkiler). - Nezahat Gökyiğit Botanik Bahçesi ve Flora Araştırmaları Derneği Yayını, Turkey.

Townsend, C. C. 1985: Fritillaria L. - Pp. 42-185 in Townsend, C. C., Guest, E. (eds). Flora of Iraq, 8. - Baghdad.

Tutin, T. G. 1980: Fritillaria L. - Pp. 14-74 in: Tutin, T. G., Heywood, V. H., Burges, N. A.(eds.), Flora Europaea, 5. - Cambridge.

Wallis, R. \& Wallis, R. B. 2003: Fritillaria frankorum, a new species. - Plantsman 2: 15-17.

Address of the authors:

Neriman Özhatay ${ }^{1}$, Rannveig Wallis ${ }^{2}$, Robert Bob Wallis ${ }^{2} \&$ Mine Koçyiğit ${ }^{1}$, ${ }^{1}$ İstanbul Üniversitesi, Eczacilık Fakültesi, Farmasötik Botanik Anabilim Dalı, Beyazit $34116 \quad$ İstanbul. E-mail: nozhatay@istanbul.edu.tr, minekocyigit@hotmail.com

${ }^{2}$ Llwyn Ifan Porthyrhyd, Carmarthen SA32 8BP. Email: robertwallis@uwclub.net 
